\title{
Understanding and perceptions of final-year Doctor of Pharmacy students about generic medicines in Karachi, Pakistan: a quantitative insight
}

This article was published in the following Dove Press journal:

Advances in Medical Education and Practice

15 May 2015

Number of times this article has been viewed

\author{
Shazia Qasim Jamshed' \\ Mohamad Izham Mohamad \\ Ibrahim² \\ Mohamad Azmi Hassali ${ }^{3}$ \\ Adheed Khalid Sharrad ${ }^{4}$ \\ Asrul Akmal Shafie ${ }^{3}$ \\ Zaheer-Ud-Din Babar ${ }^{5}$ \\ 'Pharmacy Practice, Kulliyyah of \\ Pharmacy, International Islamic \\ University Malaysia, Kuantan \\ Campus, Pahang, Malaysia; ${ }^{2}$ College \\ of Pharmacy, Qatar University, \\ Doha, Qatar; ${ }^{3}$ Discipline of Social \\ and Administrative Pharmacy, Schoo \\ of Pharmaceutical Sciences, Penang, \\ Malaysia; ${ }^{4}$ College of Pharmacy, \\ University of Basra, Basra, Iraq \\ ${ }^{5}$ School of Pharmacy, Faculty of \\ Medical and Health Sciences, \\ University of Auckland, Auckland, \\ New Zealand
}

Correspondence: Shazia Qasim Jamshed Pharmacy Practice, Kulliyyah of Pharmacy, International Islamic University Malaysia, Kuantan Campus, Pahang 25200, Malaysia Email pharmacist1992@live.com
General objective: To evaluate the understanding and perceptions of generic medicines among final-year Doctor of Pharmacy students in Karachi, Pakistan.

Methods: A 23-item survey instrument that included a question on the bioequivalence limits and Likert-type scale questions regarding the understanding and perceptions of generic medicines among the students was executed. Cronbach's alpha was found to be 0.62 .

Results: Responses were obtained from 236 final-year Doctor of Pharmacy students ( $\mathrm{n}=85$ from a publicly funded institute; $n=151$ from a privately funded institute). When comparing a brand-name medicine to a generic medicine, pharmacy students scored poorly on bioequivalence limits. More than $80 \%$ of the students incorrectly answered that all the products that are rated as generic equivalents are therapeutically equivalent to each other $(P<0.04)$. Half of the students agreed that a generic medicine is bioequivalent to the brand-name medicine $(P<0.001)$. With regard to quality, effectiveness, and safety, more than $75 \%$ of the students disagreed that generic medicines are of inferior quality and are less effective than brand-name medicines $(P<0.001)$ More than $50 \%$ of the students disagreed that generic medicines produce more side effects than brand-name medicines $(P<0.001)$.

Conclusion: The current study identified a positive perception toward generic medicines but also gaps in the understanding of generic medicines. Pharmacy students lacked a thorough understanding of the concepts of bioequivalence. Pharmacy academia should address these issues, which will help build confidence in generic medicines and increase the generic medicine use in Pakistan.

Keywords: safety, curriculum, efficacy

\section{Introduction}

Aging population and expensive medicines are the hallmarks of any health care system globally. ${ }^{1}$ The use of generic medicines is considered a cost-effective measure to curtail health care expenditures on pharmaceuticals, rendering substantial savings to the population and the government alike. ${ }^{1,2}$ The backbone of any health care system mainly comprises of physicians, pharmacists, nurses, and dentists. ${ }^{3,4}$ In order to strengthen the health care system, the role of the pharmacist is evolved from a dispenser to patient-centered caregiver, counselor, and decision-maker. ${ }^{5}$ Whether in the developed or developing nations, pharmacists are generally the direct and first line of contact with the patients and therefore signify as health-information professionals expected to give advice regarding dosage regimen, side effects, adverse effects, and drug-drug interactions and to participate in the multidisciplinary team as a practicing pharmacist. ${ }^{5-7}$ Studies from both the developed and developing countries have highlighted pharmacists' attitudes, 
perceptions, and willingness to counsel on health-related issues and pharmaceutical care, as well as their involvement in hospital rotations, to improve patient care and decrease drug costs to patients. ${ }^{8-11}$ Pharmacists are also involved in suggesting brand substitutes to patients and promoting costeffective generic alternatives, and their knowledge, perceptions, attitudes, and practices regarding generic medicine use and generic substitution were reported previously in the literature. $^{12-21}$

The health delivery system of Pakistan offers health care services for $22 \%$ of the country's population and, consequently, $78 \%$ of the population resort to out-of-pocket payment for their access to health care services. ${ }^{22}$ With more than half of the population living below the poverty line, medicine prices hike from $20 \%$ to $80 \%$ and thus pose an additional burden on the millions of Pakistani patients. ${ }^{23}$ This clearly highlights the need for cost-effective generic alternatives. Interestingly, the pharmaceutical market in Pakistan is dominated by locally manufactured pharmaceuticals, chiefly generic drugs, which covered around $90 \%$ of the country's needs in 2011. ${ }^{24}$ Multinational companies justifies for around half of the market by value, although local producers have a major share in terms of volume. ${ }^{22}$ The Government of Pakistan promotes the sale of effective and quality generic drugs at affordable prices to patients. Moreover, after the proclamation of the Drug Regulatory Authority of Pakistan (DRAP) Act, the registration process has been revisited and refurbished and thus strengthened to ensure safety efficacy and quality of drugs, and therefore the manufacturing of generic drugs is being strengthened and expedited. ${ }^{25}$ Pharmacists are generally the first point of contact with the consumers and/or patients, and this places them in an improved situation to advise health care professionals as well as consumers about generic medicines. Previous studies have highlighted that transforming prescribing and/or dispensing behavior is an ardent task. ${ }^{26,27}$ Therefore, the pharmacists, right from the stage of their academic and professional training, need to be well equipped to suggest less expensive generic alternatives. To be precise, pharmacy students are future practitioners and their knowledge and attitudes can play an important role in promoting quality use of medicines. ${ }^{28}$

\section{Literature review}

Student pharmacists can exercise reflective influence on patient care and can practice as knowledgeable and competent pharmacists, provided they are exposed to extensive clinical clerkships and hospital rotations during their academic period. Many previously published research studies took into account the role of the student pharmacist in adjusting the dose of the medicines and highlighting drug-drug interactions, drug-food interactions, side effects, and/or adverse effects, ${ }^{14,28,29}$ but only a few studies have highlighted the role of the student pharmacist in cost-saving recommendations and generic substitutions. ${ }^{29-31}$ Likewise, only a few studies have explored the knowledge and perceptions of student pharmacists about generic medicines. ${ }^{32-35}$ Therefore, it is imperative to explore the understanding and perceptions of student pharmacists about generic medicine use and generic substitution.

\section{Justification of the current research}

The pharmaceutical sector of Pakistan is objectively delineated between domestically produced generic drugs and imported branded prescription pharmaceuticals, ${ }^{22}$ and the local pharmaceutical industry captures about 70\%-85\% of the total market. ${ }^{22}$ With the patent expiry of some major innovators, the generics-dominated local pharmaceutical industry is expected to benefit more and, therefore, this current research is important.

There is no requirement that generic drugs submit effective bioequivalence data and this raises a question about the efficacy and safety of generics. ${ }^{22}$

To be precise, underutilization of generic medicines and the factors affecting underutilization of generic medicines are less explored areas in the context of Pakistan. With the local pharmaceutical industry holding a large market share (by volume) coupled with the market of Pakistan being flooded with branded generics, research into the factors affecting the contemporary issues of underutilization of generics is vital.

\section{Objectives}

The objectives of the current research were to explore the understanding and perceptions of pharmacy students about generic medicines and also to document the association of understanding and perception with sex, age, and institution. The current research also aimed to explore the views of students about the learning of bioequivalence concepts.

\section{Methodology}

There is a paucity of research evidence from developing countries regarding the understanding and perceptions of future pharmacy practitioners about generic medicines. In order to explore the research objectives both in depth and in breadth, mixed methods research is the most suitable option in the current study, as it employs both qualitative 
and quantitative methods. ${ }^{36}$ This current study also used a combination of data collection methods and data analysis in sequential phases. Therefore, in the light of the methodological design, the study was conducted in two phases, ie, a qualitative (first) and quantitative (second) phase. The first part of the study was presented and published in $2010 .{ }^{37}$ The qualitative part, in which 28 semi-structured face-to-face interviews were conducted, addressed the understanding and perceptions of final-year pharmacy students. Student pharmacists reported misunderstanding about the concept of generic medicines and expressed lack of understanding of bioequivalent concepts of generics. ${ }^{37}$

\section{Quantitative methods}

As mentioned, the current study used a mixed methods approach, and thus quantitative instrument design, quantitative data collection, and quantitative data analysis were followed subsequently after the completion of the qualitative phase (first phase).

\section{Study setting and sample}

This study was performed among pharmacy students at two pharmacy institutes in Karachi, Pakistan from January 2009 to February 2009. The researcher identified six pharmacy institutes in Karachi, Pakistan who had final-year students. On the basis of "pioneers in pharmacy education", one government-sponsored and one privately funded pharmacy institute were purposively selected for this study. Final-year Doctor of Pharmacy (Pharm D) students from a governmentsponsored $(n=85)$ and a privately funded $(n=151)$ institute were invited to participate in the study during their lecture session. In this study, the students were recruited and informed through an official notification from the dean. The office order stated the objectives of the study and were displayed on the notice board of the Faculty of Pharmacy. Participation was voluntary; however, all final-year Pharm D students participated in the study. As no personal identification was required, the students were not asked to fill out a consent form. The questionnaire was administered in the last week of the final semester, after which the students would have to appear for the final examination.

\section{Survey instrument}

As the main purpose of the qualitative phase was to establish a background for the development of a quantitative survey instrument, the questionnaire used by Hassali et al was modified in the light of qualitative analysis. ${ }^{34}$ The modified 23-item questionnaire was subjected to face validity and content validity by sending it to pharmacy academics who gave feedback on the appropriateness of items. The questionnaire was then subjected to pilot testing, and Cronbach's alpha was computed. The 23-item questionnaire consists of three sections, ie, demographic information of the students (three items); understanding and perceptions of the students regarding the bioequivalence, safety, and efficacy profile of generic medicines in comparison to brand medicines as well as generic substitution (14 items); and views of the students about the learning of bioequivalence with respect to safety and efficacy of generic medicines (five items). The 19 items used a 5 -point Likert scale ( $5=$ strongly agree to $1=$ strongly disagree), with only one item pertinent to the issue of bioequivalence regulatory limits. At the beginning of the questionnaire there was one statement about the definition of bioavailability, which was read out to the students by the researcher. The item related to the issue of bioequivalence regulatory limits read as follows:

The regulatory limits applied are that $90 \%$ confidence intervals for the ratios (generic product: brand name product) of areas under plasma drug concentration versus time curves and maximum plasma drug concentration must fall between $[\ldots]$.

For this statement, six options were given to the respondents. The correct option was $80 \%-125 \%$.

\section{Data analysis}

The data were entered into SPSS version 17.0 software. Descriptive statistics were applied to summarize the data. In order to explore the normality assumptions, descriptive statistics were performed to get skewness and kurtosis. Data were found to be not normally distributed, and crosstabulation was done to examine the relationship between the variables. In order to test the association between categorical variables, chi square was applied. In case chi square failed to fit its assumption, then Fisher's exact test was applied. A $P$-value of less than 0.05 was considered significant.

\section{Results}

The Cronbach's alpha was found to be 0.62 . The total number of final-year Pharm D students who participated in the study was 236. Demographics of the pharmacy students are shown in Table 1.

The first survey statement was related to the regulatory limits applied for bioequivalence in comparison to originator with generic alternatives. For the ease of tabulation, three 
Table I Demographics of the pharmacy students

\begin{tabular}{lll}
\hline Item & Frequency & Percent \\
\hline Age group & & \\
$20-23$ years & 194 & 82.2 \\
$24-26$ years & 42 & 17.8 \\
Sex & & \\
Male & 65 & 27.5 \\
Female & 171 & 72.5 \\
Institution & & \\
Public & 85 & 36 \\
Private & 151 & 64 \\
\hline
\end{tabular}

categories, "correct", "incorrect", and "do not know", were assigned. Out of 236 respondents, only 12 (5.1\%) students answered correctly, while the rest answered either incorrectly ( $72 \% ; n=170)$ or did not know anything about bioequivalence limits $(22.9 \% ; n=54)$.
Tables 2 and 3 show the responses of final-year Pharm D students regarding their understanding and perceptions of generic medicines as well as students' views about the learning of bioequivalence with respect to safety and efficacy of generic medicines.

\section{Understanding of generic medicines}

A medicine that is considered a "generic equivalent" will demonstrate therapeutic equivalence to brand-name products, but not all generic equivalents will demonstrate therapeutic equivalence to each other. When questions about this were asked of the respondents, more than $80 \%$ of the students incorrectly "strongly agreed" $(30.1 \% ; n=71)$ and "agreed" $(53.8 \% ; n=127)$ that all generic products of a particular medicine that are rated as generic equivalents are therapeutically equivalent to each other. This response showed statistical

Table 2 Understanding of and perceptions toward generic medicines

\begin{tabular}{|c|c|c|c|c|c|c|c|}
\hline Statements/items & $\begin{array}{l}\text { Strongly } \\
\text { agree } \\
\text { n (\%) }\end{array}$ & $\begin{array}{l}\text { Agree } \\
\text { n (\%) }\end{array}$ & $\begin{array}{l}\text { Neutral } \\
\text { n (\%) }\end{array}$ & $\begin{array}{l}\text { Disagree } \\
\text { n (\%) }\end{array}$ & $\begin{array}{l}\text { Strongly } \\
\text { disagree } \\
\text { n (\%) }\end{array}$ & $\begin{array}{l}\text { Sex } \\
P \text {-value }\end{array}$ & $\begin{array}{l}\text { University } \\
P \text {-value }\end{array}$ \\
\hline $\begin{array}{l}\text { All generic products of a particular medicine that } \\
\text { are rated as generic equivalents are therapeutically } \\
\text { equivalent to the innovator brand product }\end{array}$ & $59(25.0)$ & $|2|(5 \mid .3)$ & $15(6.4)$ & $36(15.3)$ & $5(2.1)$ & 0.168 & 0.513 \\
\hline $\begin{array}{l}\text { All generic products of a particular medicine that } \\
\text { are rated as generic equivalents are therapeutically } \\
\text { equivalent to each other }\end{array}$ & 7I (30.1) & $127(53.8)$ & II (4.7) & $26(11.0)$ & I (0.4) & 0.104 & $0.028^{*}$ \\
\hline $\begin{array}{l}\text { A generic medicine is bioequivalent } \\
\text { to a brand name medicine }\end{array}$ & $27(11.4)$ & $91(38.6)$ & $36(15.3)$ & $70(29.7)$ & $12(5.1)$ & $0.001 *$ & 0.595 \\
\hline $\begin{array}{l}\text { A generic medicine must be in the same dosage form } \\
\text { (eg, tablet, capsule) as the brand name medicine }\end{array}$ & $26(11.0)$ & $65(27.5)$ & 27 (II.4) & $96(40.7)$ & $22(9.3)$ & 0.366 & $0.001 *$ \\
\hline $\begin{array}{l}\text { A generic medicine must contain the same dose } \\
\text { as the brand name medicine }\end{array}$ & $39(16.5)$ & $98(4 \mid .5)$ & $16(6.8)$ & $76(32.2)$ & $7(3.0)$ & $0.047^{*}$ & 0.573 \\
\hline $\begin{array}{l}\text { Generic medicines are of inferior quality } \\
\text { to branded drugs }\end{array}$ & $4(1.7)$ & $31(13.1)$ & $22(9.3)$ & $127(53.8)$ & $52(22.0)$ & 0.485 & $0.001 *$ \\
\hline $\begin{array}{l}\text { Generic medicines are less effective than } \\
\text { brand name medicines }\end{array}$ & $6(2.5)$ & $21(8.9)$ & $21(8.9)$ & $139(58.9)$ & $49(20.8)$ & 0.115 & $0.001 *$ \\
\hline $\begin{array}{l}\text { Generic medicines produce more side-effects } \\
\text { than brand name medicines }\end{array}$ & $4(1.7)$ & $40(16.9)$ & $45(19.1)$ & $109(46.2)$ & $38(16.1)$ & 0.164 & $0.001 *$ \\
\hline $\begin{array}{l}\text { Generic medicines are less expensive than } \\
\text { brand name medicines }\end{array}$ & $28(11.9)$ & 91 (38.6) & $40(16.9)$ & $65(27.5)$ & $12(5.1)$ & 0.101 & 0.149 \\
\hline $\begin{array}{l}\text { Brand name medicines are required to meet } \\
\text { higher safety standards than generic medicines }\end{array}$ & $19(8.1)$ & $104(44.1)$ & $33(14.0)$ & $60(25.4)$ & $20(8.5)$ & $0.006 *$ & $0.001 *$ \\
\hline $\begin{array}{l}\text { From the knowledge I have, I'm confident } \\
\text { in dispensing in future by generic drug name } \\
\text { rather than brand name }\end{array}$ & $70(29.7)$ & $110(42.4)$ & $34(14.4)$ & $28(11.9)$ & $4(1.7)$ & $0.047^{*}$ & 0.334 \\
\hline $\begin{array}{l}\text { I find it easier to recall a medicine's therapeutic } \\
\text { class using generic names rather than brand names }\end{array}$ & $116(49.2)$ & $99(41.9)$ & $7(30.7)$ & II (4.7) & $3(1.3)$ & 0.230 & 0.191 \\
\hline $\begin{array}{l}\text { I believe that pharmacists are one of the most } \\
\text { important health care professionals to give advice } \\
\text { on generic medicines }\end{array}$ & I7| (72.5) & $62(26.3)$ & I (4.0) & I (4.0) & I (4.0) & $0.002^{*}$ & 0.508 \\
\hline $\begin{array}{l}\text { I believe that multinational products are of good } \\
\text { quality than local company products }\end{array}$ & $|2|(5 \mid .3)$ & $93(39.4)$ & II (4.7) & II (4.7) & 0 & 0.671 & 0.510 \\
\hline
\end{tabular}

Notes: aPublic or private university. $* P<0.05$. 
Table 3 Students' views on bioequivalence

\begin{tabular}{|c|c|c|c|c|c|c|c|}
\hline Statements/items & $\begin{array}{l}\text { Strongly } \\
\text { agree } \\
\text { n (\%) }\end{array}$ & $\begin{array}{l}\text { Agree } \\
\text { n (\%) }\end{array}$ & $\begin{array}{l}\text { Neutral } \\
\text { n (\%) }\end{array}$ & $\begin{array}{l}\text { Disagree } \\
\text { n (\%) }\end{array}$ & $\begin{array}{l}\text { Strongly } \\
\text { disagree } \\
\text { n (\%) }\end{array}$ & $\begin{array}{l}\text { Sex } \\
P \text {-value }\end{array}$ & $\begin{array}{l}\text { University } \\
P \text {-value }\end{array}$ \\
\hline $\begin{array}{l}\text { I have not been introduced to the issues of bioequivalence } \\
\text { for generic medicines during my pharmacy education }\end{array}$ & $14(5.9)$ & $44(18.6)$ & $16(6.8)$ & $104(44.1)$ & $58(24.6)$ & 0.012 & $0.002 *$ \\
\hline $\begin{array}{l}\text { I need more information on how bioequivalence tests } \\
\text { are conducted for generic medicines }\end{array}$ & $95(40.3)$ & $128(54.2)$ & II (4.7) & $2(0.8)$ & 0 & 0.536 & $0.001 *$ \\
\hline $\begin{array}{l}\text { I need more information on the issues pertaining } \\
\text { to the efficacy and safety of generic medicines }\end{array}$ & $69(29.2)$ & $152(64.4)$ & $9(3.8)$ & $5(2.1)$ & I $(0.4)$ & 0.056 & 0.099 \\
\hline $\begin{array}{l}\text { I believe that pharmacy curriculum should focus } \\
\text { on cost-effective dispensing }\end{array}$ & $64(27.1)$ & $149(63.1)$ & II (4.7) & $12(5.1)$ & 0 & 0.396 & $0.001 *$ \\
\hline $\begin{array}{l}\text { I believe that pharmacy curriculum should involve aspects } \\
\text { on National Drug Policy and National Essential Drug List }\end{array}$ & $66(28.0)$ & $142(60.2)$ & $23(9.7)$ & $5(2.1)$ & 0 & 0.655 & 0.228 \\
\hline
\end{tabular}

Notes: aPublic or private university. $* P<0.05$.

significance with respect to university $(P<0.046)$, and higher association was observed in private university students.

Half of the students $(50 \% ; n=118)$ "strongly agreed" and "agreed" that a generic medicine is bioequivalent to the brand-name medicine. In terms of dosage form, nearly $40 \%(38.5 \% ; \mathrm{n}=91)$ of the students agreed that generic medicine must be available in the same dosage form as brand-name medicine. These responses showed statistical significance with respect to sex and university $(P<0.001)$, and greater association was noted among the males of the public university.

\section{Understanding of the safety standards of generic medicines}

Interestingly, the understanding about the requirements of safety standards of brands and generic medicines seemed to be divided. Just over half of the pharmacy students (52.2\%; $\mathrm{n}=123$ ) wrongly believed that brand-name medicines are required to meet higher safety standards than generic medicines. The response showed statistical significance with respect to university $(P<0.001)$.

\section{Perceptions toward generic medicines}

In terms of quality, effectiveness, and safety, more than $75 \%$ of the students either "disagreed" or "strongly disagreed" that generic medicines are of inferior quality $(75.8 \% ; n=179)$ and are less effective than brand-name medicines (79.7\%; $\mathrm{n}=188)$. More than half of the students "disagreed" $(62.3 \%$; $\mathrm{n}=147$ ) that generic medicines produce more side effects than brand-name medicines. These responses showed statistical significance with respect to university $(P<0.001)$, with better perceptions observed in public university students. More than $70 \%$ of the students $(72.1 \% ; n=180)$ expressed their confidence in dispensing by generic name rather than brand name. This showed a statistical significance with respect to sex $(P<0.04)$, with greater association seen in female student pharmacists.

\section{Views on bioequivalence}

With regard to students' views about bioequivalence, a large number of students $(68.7 \% ; n=162)$ "strongly disagreed" and "disagreed" that they are not introduced to the issues of bioequivalence for generic medicines during pharmacy education, but more than $90 \%(94.5 \%$; $n=223)$ expressed their curiosity to know more about bioequivalence tests for generic medicines. Both of these responses were found to be statistically significant with respect to university $(P<0.002$; $P<0.001$ ), with better views reflected by public university students. Although not statistically significant, it is worth mentioning that the majority of the pharmacy students believed that the pharmacy curriculum should include aspects on the National Drug Policy and the National Essential Drug List $(88.2 \% ; n=208)$.

\section{Discussion}

In the present era of spiraling health care costs, there is a need for cost-effective generic alternatives. The Government of Pakistan endorsed this concept and thus educators of health care professionals are responsible for teaching and training future practitioners about the utilization of cost-effective medicines. In order to deal with the contemporary issues of underutilization of generic medicines, it is imperative that health care professionals demonstrate understanding of and sound perceptions toward generic alternatives. Thus, the current research was carried out to explore the understanding and perceptions of pharmacy students about generic medicines.

Moreover, to the best of our knowledge, the current study is the first of its kind in evaluating final-year Pharm D 
students' understanding and perceptions of generic medicines in Pakistan. The current study showed gaps in the understanding of basic concepts of generic medicines in final-year Pharm D students. This is in accordance with the results of the qualitative study, in which student pharmacists showed gaps in understanding of the basic concepts of generic medicines and their bioequivalence criteria. ${ }^{37}$ Likewise, studies done in Australia, Iraq, and Bangladesh on future pharmacy and medical practitioners also reported knowledge gaps and lack of understanding of issues related to the use of generic medicines. ${ }^{32-34}$ In the current research, a higher proportion of correct responses was measured from government-sponsored university students. This is most likely due to different teaching styles in each university, which is attributed to highly qualified and experienced teaching staff in government-sponsored universities. With regard to perceptions toward generic medicines, the students seem to be positive. In the current research, a large majority of students disagreed that generic medicines are of inferior quality and are less effective than brand-name medicines. Nearly half of the students disagreed that generic medicines produce more side effects than brand-name medicines. Female students from the government-sponsored university showed higher confidence in dispensing by generic name rather than brand name. Moreover, in the current study, a higher proportion of students from the government-sponsored university showed eagerness to know about bioequivalence tests.

The findings of the current study do not correlate well with the previous studies done in Australia and Bangladesh, wherein pharmacy preregistrants and medical students considered generic medicines to be inferior, less effective, and having more side effects than brand-name medicines. ${ }^{32,34}$

The differences in findings between the current study and other international studies may be due to the genericsdominated local industry in Pakistan, resulting in the sensitization of the faculty towards generic medicines. Furthermore, lectures on generic medicines might have been conducted in the final semester. Moreover, orientation sessions from the local pharmaceutical industries in both pharmacy universities in the final semester may partly contribute to the differences in the understanding and perceptions of generic medicines when compared to previous studies. ${ }^{32,34}$

As highlighted by McGivney, training of future pharmacy practitioners in practice sites contributes to better patient care. ${ }^{38}$ The implementation of a similar concept to hands-on training to future pharmacy practitioners in Pakistan may result in better quality of care for patients. ${ }^{38}$ Regarding bioequivalence issues, students admitted that they were introduced well to the concepts, but a poor response to questions about bioequivalence limits indicates a lack of understanding of this concept. These findings reflect the complexity of topics of pharmacokinetics and biopharmaceutics that are difficult for the students to understand. A special course emphasizing bioequivalence and bioequivalence testing of generic medicines and highlighting the patients' needs regarding generic substitution and interchangeability of brands with generic formulations could be helpful for future pharmacy practitioners. Moreover, a blended learning approach to teaching pharmacokinetics principles as well as mutual reviewing and discussion among teachers and students of the pharmacokinetics studies previously reported in the literature should be emphasized in a pharmacy curriculum. $^{39}$

The basic principles of economics are taught in secondyear Pharm D in both of the surveyed universities, but the application of basic concepts of supply and demand, drug pricing, and the merits and disadvantages of brand-name medicines and generic medicines are lacking. A study done in USA reported that, as compared to pharmacists, pharmacy students made more recommendations to curtail health care expenses. ${ }^{29}$ Thus, incorporating case studies in economics courses in a pharmacy curriculum will help future practitioners to develop into counselors of cost-effective regimens. Moreover, pharmacy students need to have knowledge about the National Drug Policy and the National Essential Drug List that contain information on cost-effective medicines. A pharmacoeconomics course, which is included as a subject in many pharmacy curricula globally, ${ }^{40-42}$ is recommended to be included in the pharmacy curriculum in Pakistan.

\section{Limitations of the study}

Regarding the limitations in the current study, the student participants were from two pharmacy institutes only, and this restricts the extrapolation of findings to other Doctor of Pharmacy programs in Pakistan.

\section{General conclusion and recommendation}

In the current study, gaps in understanding of the basic concepts of generic medicine and their bioequivalence were documented. This should be tackled by pharmacy educators, as pharmacists are the core loop in the health care chain, and their knowledge of generic medicines can inform both the prescriber and the patient on cost-effective regimens. Interestingly, in relation to perceptions, pharmacy students showed positive perceptions toward generic medicines. 
With regard to pharmacy curriculum, future strategies should be directed toward 1-year preregistration training or residency in the field of interest such as at a hospital or in industry. Universities are recommended to sign a memorandum of understanding with different hospitals and pharmaceutical industries to foster a hands-on learning experience in the final professional year.

\section{Disclosure}

All the authors hereby declare that are no actual or potential conflicts of interest including any personal, financial, or other relationships with other people or organizations within 3 years of beginning the work submitted that could inappropriately influence or bias the work. The authors hereby declare that Universiti Sains Malaysia provided a grant only to collect the data and was not in any way involved in the study design, analysis and interpretation of data, writing of article, or submission of the article to the journal.

\section{References}

1. Godman B, Shrank W, Wettermark B, et al. Use of generics - a critical cost containment measure for all healthcare professionals in Europe? Pharmaceuticals. 2010;3(8):2470-2494.

2. King DR, Kanavos P. Encouraging the use of generic medicines: implications for transition economies. Croat Med J. 2002;43(4):462-469.

3. Anyangwe SC, Mtonga C. Inequities in the global health workforce: the greatest impediment to health in sub-Saharan Africa. Int J Environ Res Public Health. 2007;4(2):93-100.

4. Stilwell B, Diallo K, Zurn P, Vujicic M, Adams O, Dal Poz M. Migration of health-care workers from developing countries: strategic approaches to its management. Bull World Health Organ. 2004;82:595-600.

5. Jamshed SQ, Shamsudin SH. Reflective writing in pharmacy practice. Int J Pharm Pract. 2014;22(1):101-102.

6. Toklu HZ, Hussain A. The changing face of pharmacy practice and the need for a new model of pharmacy education. J Young Pharm. 2013;5(2):z38-z40.

7. Freeman CR, Cottrell WN, Kyle G, Williams ID, Nissen LM. Chronicles of a primary care practice pharmacist. Integrated Pharmacy Research and Practice. 2012;1:13-18.

8. El Hajj MS, Hammad AS, Afifi HM. Pharmacy students' attitudes toward pharmaceutical care in Qatar. Ther Clin Risk Manag. 2014;10: 121-129.

9. Dashti-Khavidaki S, Khalili H, Hamishekar H, Shahverdi S. Clinical pharmacy services in an Iranian teaching hospital: a descriptive study. Pharm World Sci. 2009;31(6):696-700.

10. Feifer RA, Greenberg L, Rosenberg-Brandl S, Franzblau-Isaac E. Pharmacist counseling at the start of therapy: patient receptivity to offers of in-person and subsequent telephonic clinical support. Popul Health Manag. 2010;13(4):189-193.

11. Palaian S, Prabhu M, Shankar PR. Patient counseling by pharmacist a focus on chronic illness. Pak J Pharm Sci. 2006;19(1):65-72.

12. Erramouspe J. Impact of education by clinical pharmacists on physician ambulatory care prescribing of generic versus brand-name drugs. DICP. 1989;23(10):770-773.

13. Summers KH. Pharmacist intervention in safe and effective conversion of brand to generic drugs. J Manag Care Pharm. 2005;11(9):777.

14. Pham DQ. Evaluating the impact of clinical interventions by PharmD students on internal medicine clerkships: the results of a 3 year study. Ann Pharmacother. 2006;40(9):1541-1545.
15. Jamshed SQ, Hassali MAA, Ibrahim MIM, Shafie AA, Babar Z. Knowledge, perception and attitude of community pharmacists towards generic medicines in Karachi, Pakistan: a qualitative insight. Tropical Journal of Pharmaceutical Research. 2010;9(4):409-415.

16. Dunne SS, Shannon B, Cullen W, Dunne CP. Perceptions and attitudes of community pharmacists towards generic medicines. J Manag Care Pharm. 2014;20(11):1138-1146.

17. Babar ZU, Polwin A, Kan SW, et al. Exploring pharmacists' opinions regarding PHARMAC's interventions in promoting brand changes. Res Social Adm Pharm. 2015;11(1):96-110.

18. Awaisu A, Kheir N, Ibrahim MI, et al. Knowledge, attitudes, and practices of community pharmacists on generic medicines in Qatar. Int J Clin Pharm. 2014;36(2):394-404.

19. Babar Z-U-D, Awaisu A. Evaluating community pharmacists' perceptions and practices on generic medicines: a pilot study from Peninsular Malaysia. Journal of Generic Medicines: The Business Journal for the Generic Medicines Sector. 2008;5(4):315-330.

20. Basak SC, Sathyanarayana D. Exploring knowledge and perceptions of generic medicines among drug retailers and community pharmacists. Indian J Pharm Sci. 2012;74(6):571-575.

21. Auta A, Bala ET, Shalkur D. Generic medicine substitution: a crosssectional survey of the perception of pharmacists in North-Central, Nigeria. Med Princ Pract. 2014;23(1):53-58.

22. Business Monitor International. Pakistan Pharmaceutical and Healthcare Report Q1 2014. Business Monitor International; 2014. Available from: http://www.researchandmarkets.com/reports/2691063/pakistan_pharmaceuticals_and_healthcare_report_q1.pdf. Accessed April $16,2015$.

23. Abbasi W. Drug prices pushed up by 20 to $80 \mathrm{pc}$ despite govt orders. The News. January 09, 2014. Available from: http://www.thenews.com. pk/Todays-News-13-27825-Drug-prices-pushed-up-by-20-to-80pcdespite-govt-orders. Accessed December 12, 2014.

24. Babar Z, Jamshed S, Malik A, Gilani AH. The pharmaceutical industry, intellectual property rights and access to medicines in Pakistan. In: Löfgren H, Williams OD, editors. The New Political Economy of Pharmaceuticals Production, Innovation and TRIPS in the Global South. London: Palgrave MacMillan; 2014: $167-184$.

25. Imaduddin. Govt promoting sale of effective, quality of generic drugs: NA told. Business Recorder. October 22, 2014. Available from: http://www.brecorder.com/pakistan/politics-a-policy/201103govt-promoting-sale-of-effective-quality-of-generic-drugs-na-told. html. Accessed December 12, 2014.

26. Wensing M, Grol R. Single and combined strategies for implementing changes in primary care: a literature review. Int J Qual Health Care. 1994;6(2):115-132.

27. Brand P, Clear P, Keen S, Hobbs M, Appel S, Coote W. Brand substitution. Australian Pharmacist. 1995;14:646-649.

28. Chisholm MA, Hawkins DW. Analysis of pharmacotherapy recommendations provided by Doctor of Pharmacy clerkship students. Journal of Pharmacy Teaching. 1996;5(4):3-12.

29. Freml JM, Farris KB, Fang G, Currie J. Iowa Priority's Brown Bag Medication Reviews: a comparison of pharmacy students and pharmacists. Am J Pharm Educ. 2004;68(2):50.

30. McCollum M, Nuffer W, Ellis SL, Turner CJ. Physician acceptance of pharmacotherapy recommendations made by pharmacy students in a rural pharmacy-based diabetes care and education clinic. Am J Pharm Educ. 2009;73(2):24.

31. Slaughter RL, Erickson SR, Thomson P. Clinical interventions provided by doctor of pharmacy students. Ann Pharmacother. 1994;28(5): 665-670.

32. Siam MKS, Khan A, Khan TM. Medical and pharmacy students' knowledge and perceptions about generic medicines in Bangladesh. J Pharm Health Serv Res. 2013;4(1):57-61.

33. Sharrad AK, Hassali MA. Knowledge and perceptions of final year medical students in Iraqi universities about generic medicines. Journal of Bioequivalence and Availability. 2011;3:86-91. 
34. Hassali MA, Kong DCM, Stewart K. Knowledge and perceptions of recent pharmacy graduates about generic medicines. Pharmacy Education. 2007;7(1).

35. Holmes JH, Dennison KM. Student pharmacists' perceptions of generic and branded drugs. J Pharm Mark Manage. 1992;6(4):71-83.

36. Tashakkori A, Creswell JW. Editorial: exploring the nature of research questions in mixed methods research. J Mix Methods Res. 2007;1(3): 207-211.

37. Jamshed S, Hassali MA, Ibrahim MIM, Babar Z. Understanding and perception of final year pharmacy students towards generic medicines in Pakistan: an exploratory qualitative study. Paper presented at: 16th International Social Pharmacy Workshop 2010; August 23-26, 2010; Lisbon.

38. McGivney MS. Building an Advanced Pharmacy Practice Experience (APPE) site for Doctor of Pharmacy students. Currents in Pharmacy Teaching and Learning. 2009;1(1):25-32.
39. Edginton A, Holbrook J. A blended learning approach to teaching basic pharmacokinetics and the significance of face-to-face interaction. $\mathrm{Am}$ J Pharm Educ. 2010;74(5):88.

40. Reddy M, Rascati K, Wahawisan J, Rascati M. Pharmacoeconomic education in US colleges and schools of pharmacy: an update. Am J Pharm Educ. 2008;72(3):51.

41. Soliman AM, Hussein M, Abdulhalim AM. Pharmacoeconomic education in Egyptian schools of pharmacy. Am J Pharm Educ. 2013; $77(3): 57$.

42. Nwokeji ED, Rascati KL. Pharmacoeconomic education in colleges of pharmacy outside of the United States. Am J Pharm Educ. 2005; 69(3):52.

\section{Publish your work in this journal}

Advances in Medical Education and Practice is an international, peerreviewed, open access journal that aims to present and publish research on Medical Education covering medical, dental, nursing and allied health care professional education. The journal covers undergraduate education, postgraduate training and continuing medical education including emerging trends and innovative models linking education, research, and health care services. The manuscript management system is completely online and includes a very quick and fair peer-review system. Visit http://www.dovepress.com/testimonials.php to read rea quotes from published authors.

Submit your manuscript here: http://www.dovepress.com/advances-in-medical-education-and-practice-journal 